\title{
ZADOVOLJSTVO POSLOM, MOTIVACIJA UČITELJA ZA RAD I POTICANJE RAZVOJA KOMPETENCIJA UČENIKA
}

\author{
Edita Borić \\ Fakultet za odgojne i obrazovne znanosti, \\ Sveučilište Josipa Jurja Strossmayera \\ u Osijeku, Hrvatska \\ editaboric27@gmail.com
}

Primljeno: 2. 11. 2017.

\begin{abstract}
Cilj istraživanja bio je ispitati u kojem stupnju učitelji potiču kompetencije kod učenika te koliko su zadovoljni svojim poslom i motivirani za rad. Cilj je bio i ispitati povezanost stupnja u kojem učitelji potiču kompetencije kod učenika, zadovoljstva poslom i motivacije za rad te godina radnog staža. Sudionici su bili učitelji razredne nastave $(N=341)$. Korišten je Upitnik poticanja razvoja kompetencija učenika, učiteljskog zadovoljstva poslom i motivacije za rad (Borić i Borić, 2013) konstruiran za potrebe istraživanja. Rezultati faktorske analize pokazali su kako se upitnik sastoji od: (1) subskale poticanja razvoja kompetencija učenika i (2) subskale zadovoljstva poslom i motivacije za rad učitelja. Utvrđeno je da postoji pozitivna korelacija $(r=$ 0,360, p<0,05) između subskala. Moguće je zaključiti kako su učitelji u prosjeku visoko zadovoljni svojim poslom i motivirani za rad te se kod učenika trude razviti kompetencije u viskom stupnju. Rezultati su pokazali kako između godina radnog staža te zadovoljstva poslom $i$ motivacije za rad postoji statistički značajna niska pozitivna korelacija $r=0,176, p<0,01$.
\end{abstract}

Ključne riječi: kvaliteta učitelja, radni staž, razredna nastava

\section{Uvod}

Nastava je dinamičan proces koji podrazumijeva zajednički rad učitelja i učenika. To je oblik organiziranog učenja kojemu je cilj odgoj i obrazovanje učenika (Jelavić, 1998). Tijekom nastave učitelj odabra- 
nim metodama izlaže nastavni sadržaj i učenicima daje različite zadatke. On odabire i priprema izvore nastavnih sadržaja te načine njihova prikazivanja s namjerom da učenicima olakša razumijevanje i usvajanje predviđenog sadržaja (Bognar i Matijević, 2005).

Današnji cilj nastave je podržati učenike u razvoju konkretnih sposobnosti. Nekadašnje enciklopedijsko znanje zamjenjuje se razvijanjem sposobnosti razumijevanja, rješavanja problema i praktične primjene znanja uz stjecanje umijeća koja pridonose kvaliteti življenja učenika u suvremenom svijetu (Vizek Vidović i sur., 2003). Sve više se ističe značaj razvijanja općih strategija učenja, razvoj sposobnosti učenika za samostalno upravljanje procesom učenja, za samoevaluaciju i svijest o vlastitim aktivnostima učenja prakse (Lončarić i Pejić Papak, 2009). Naglasak je na nastavi, odnosno poučavanju koje potiče učenje. Nova promišljanja nastavnoga procesa obilježena su specifičnim odnosima učenika i učitelja usmjerenima motiviranju i osamostaljivanju učenika. Konačni cilj je samoregulirano učenje koje pretpostavlja razvoj učenikove osobnosti, individualnosti i originalnosti (Tot, 2010).

Postoji direktna veza između razumijevanja u učenju i načina poučavanja (Lončarić i Pejić Papak, 2009). Kvalitetno je ono poučavanje u kojemu su stvoreni uvjeti za reorganizaciju učenikova osobnog razumijevanja na temelju refleksije. To je nastava u kojoj učenik koristi određene podatke kao mogućnosti za daljnju analizu i potkrepljivanje svojih razmišljanja, gdje vlastita značenja povezuje, uopćava i strukturira u odnosu na prethodna. Tri šira skupa indikatora kvalitete nastave su: stručnost učitelja (kompetencija), poznavanje i primjena metodičkodidaktičkih principa u nastavi te motivacija za nastavu i odnos prema učenicima. Zahtjevnost poučavanja ne proizlazi iz strukture poučavanih s obzirom na njihovu dob ili stupanj obrazovanja (mladi ili stari, obrazovani ili neobrazovani), nego prije svega iz njihovih motiva, odnosno smisla koji oni vide u tome što rade (Azevedo i Hadwin, 2005).

Motivacija je utjecaj koji izaziva, usmjerava i održava željeno ponašanje ljudi (Reeve, 2009). Ekstrinzična motivacija ponašanje potiče nekim vanjskim motivom, dok intrinzična motivacija pokreće osobu iznutra, a ponašanje koje je tako motivirano puno se lakše i uspješnije obavlja (Borić i Borić, 2013). Motivatori su stvari koje pojedinca potiču na djelovanje i utječu na njegovo ponašanje. Oni stvaraju razliku u onome što će osoba činiti; to su određene nagrade ili poticaji koji pojačavaju žudnju za zadovoljenjem želja (Čorkalo Biruški, 2009). Motiva- 
cija za posao odnosi se na one varijable koje djeluju na radnikovu produktivnost. Intrinzični motivatori za posao najčešće su izazovan posao, odgovornost, postignuće i uspjeh, priznanje, napredovanje i mogućnost rasta (samoaktualizacija). Ekstrinzični čimbenici su međuljudski odnosi, plaća, radni uvjeti, politika i administracija poduzeća u kojemu se radi i sigurnost posla (Mihaliček i Rijavec, 2009).

Čimbenicima motivacije za posao kod učitelja bavili su se mnogi istraživači. Kindred i sur. (1990, u: Resman, 2001) navode da su najvažniji čimbenici motivacije učitelja za rad zadovoljstvo u radu i spoznaja da je rad koji obavljaju cijenjen, a Thody (1992) tvrdi da je ozračje kolegijalnosti najsnažniji motivacijski čimbenik. Low i Marican (1993) navode da je najvažnije poštovanje, samoaktualizacija, sigurnost, autonomija, pripadnost, orijentacija na postignuće, profesionalni izazov i identitet zadatka, a Roter i Juran (1994, u: Resman, 2001) da samo dobra plaća nije ni najsnažniji ni najvažniji motiv za rad u školi. I Ozcan (1996, u: Dörnyei, 2001) smatra da su učiteljima plaće manje važne, a naglašava važnost intrinzičnih nagrada. Blackburn (1997, u: Dörnyei, 2001) navodi da su važne određene nagrade, članstva u profesionalnim društvima, mogućnosti pripremanja određenih materijala za poučavanje i sl. Resman (2001) navodi da je rad s učenicima najsnažniji motiv učitelja, a važno im je i zadovoljstvo kada vide da učenici uče i napreduju, dobri radni uvjeti, mogućnosti napredovanja i sl. Rezultati istraživanja Nikolić (2013) pokazali su da su učiteljima najvažniji mogućnost primjene vlastitih znanja i sposobnosti, samostalnost i odgovornost $\mathrm{u}$ radu, osiguranje sigurne i stabilne budućnosti, a najmanje sudjelovanje u upravljanju i odlučivanju, ugled posla i visina osobnog dohotka.

Donedavna uglavnom zanemarena motivacija učitelja postaje područje sve intenzivnijega istraživačkog interesa (Woolfolk, 2008) u čijem su fokusu sve složeniji modeli međuodnosa različitih motivacijskih varijabli (Malmberg, 2006). Jedna od važnih varijabli je i zadovoljstvo poslom, odnosno složen stav koji uključuje određene pretpostavke i vjerovanja o tom poslu (kognitivnu komponentu), osjećanja prema poslu (afektivnu komponentu) te ocjenu posla (evaluacijsku komponentu). Istraživači u ovom području pozornost sve više posvećuju samim počecima profesionalnog razvoja učitelja te faktorima koji igraju značajnu ulogu u njihovim profesionalnim odabirima (Sinclair, Dowson i McInerney, 2006). Posebno su intenzivna istraživanja motivacije za poučava- 
nje i percepcije budućega zanimanja, koja se sve češće zasnivaju na provjerenim motivacijskim teorijama (Malmberg, 2006; Watt i Richardson, 2008). Upravo su samoprocjenjene sposobnosti za poučavanje, socijalna $i$ intrinzična vrijednost poučavanja te prethodna pozitivna iskustva s učenjem i poučavanjem najvažniji razlozi za odabir učiteljske profesije kod studenata učiteljskih i nastavničkih studija na australskim sveučilištima (Richardson i Watt, 2006), a ti su aspekti motivacije studenata prve godine bili i najviše povezani s procjenama zadovoljstva izborom zanimanja te planiranoga profesionalnog angažmana na kraju studija (Watt i Richardson, 2007). Zadovoljstvo izborom profesije povezano je s procjenama vlastitoga angažmana u budućoj profesiji i na početku i na kraju studija, te je očito bitan motivacijski čimbenik pri odlukama o budućim ulaganjima u vlastito profesionalno usavršavanje i kvalitetu poučavanja, ali i o ostanku u učiteljskoj profesiji tijekom duljeg vremena (Watt, Richardson i Tysvaer, 2007). Prema ovome modelu i varijable poput samoefikasnosti za učenje, samopoimanja, motivacije za učenje i temeljnih psiholoških potreba mogu imati važnu ulogu u razvoju profesionalnog identiteta budućih učitelja te mogu biti značajnom odrednicom motivacije za poučavanje. Posebno važnim čini se razvoj intrinzične motivacije za poučavanje, jer se upravo takva motivacija učitelja pokazala povezanom s kvalitetnijim pristupom poučavanju koji potiče autonomiju učenika (Pelletier, Chantal i Legault, 2002), a time i njihovu intrinzičnu motivaciju i bolji uspjeh u učenju (Reeve, Bolt i Cai, 1999).

Motiviranje za nastavu obuhvaća sve što izvana ili iznutra potiče na učenje, usmjerava ga, određuje mu intenzitet, trajanje i kakvoću (Marentič Požarnik, 2000). Čini se da su motivirani učenici malobrojni u razredu pa je pronaći što sve djeluje na motiviranost učenika važan zadatak za učitelje. Na motivaciju učenika teško je utjecati jer su njihovi razvojni problemi usmjereni na sadržaje koji se nalaze izvan nastave. Iz tog je razloga potrebno posebno analizirati izvannastavne sadržaje kako bi se našao pravi pristup učenicima. Motivaciji za učenje pridonosi i ozračje koje vlada u razredu i odnos između učitelja i učenika. Učenik koji cijeni učitelja više će se potruditi i oko nečega što ga baš i ne zanima ili što ne smatra potrebnim. Ako učenike stalno potičemo i svojim načinom rada motiviramo na učenje, oni će postizati dobre rezultate i takav će rad donijeti zadovoljstvo i učenicima i učiteljima (Andrilović, Čudina-Obradović, 1996). 
Između motivacije za učenje i rezultata u učenju postoji velika povezanost. Dobri rezultati osnažuju motivaciju, a visoka motiviranost vodi do dobrih rezultata u učenju (Kovač i sur., 2005). Osobine motiviranog učenika vrlo su jasne: takvi učenici su u učenju zainteresirani, znatiželjni, aktivni, često se oduševljavaju, uporni su i ne odustaju kada naiđu na teškoće. Dulje se školuju, uče i znaju više te su zadovoljniji sobom nego nemotivirani učenici (Andrilović, Čudina Obradović, 1996).

Ono što je posebno važno jest povezanost vrsta motivacije učenika (vanjska, unutarnja, usmjerena postignuću) s pristupima učenju (površinski, dubinski, strateški pristup učenju) (Vizek Vidović i sur., 2003). Istraživanja govore da učenici pristupaju učenju na jedan od tri načina: dubinski pristup, površinski pristup i strateški pristup. Učenici koji učenju pristupaju dubinski žele uočiti smisao predmeta, razumjeti, angažirati se, povezivati, analizirati, smještati u kontekst. Učenici s površinskim pristupom nisu prvenstveno zainteresirani za razumijevanje predmeta - njihova je temeljna motivacija dobiti dobru ocjenu. Zanima ih što se treba učiniti za dobivanje ocjene, a ne za postizanje kvalitetnih znanja. Učenici koji zauzimaju strateški pristup učenju (pristup postignuća) žele ostvariti dobar uspjeh u nastavi i organizirati se tako da postignu dobar omjer između ulaganja napora i postizanja rezultata. Iako je jasno da je dubinski pristup učenju onaj koji je poželjan, istraživanja i iskustva govore da je i kombinacija dubinskog i strateškog pristupa također vrlo učinkovita. Motivacija za učenje i pristupi učenju u velikoj su mjeri povezani s učiteljem: njegovim koncepcijama učenja i poučavanja, pogotovo njegovim pristupom poučavanju. Učitelji koji smatraju da je poučavanje u osnovi osnaživanje razumijevanja ili oni koji drže da je poučavanje primarno prijenos informacija imat će vjerojatno bitno različite pristupe poučavanju u konkretnim nastavnim situacijama (Vizek Vidović i sur., 2003).

Istraživanja su utvrdila kako je kvaliteta učitelja vrlo važan školski faktor koji pridonosi obrazovnom uspjehu učenika (Marušić, Ivanec i Vizek Vidović, 2010), no trajan nedostatak kvalificiranih učitelja, kao i njihov sve češći odlazak iz profesije, problem je s kojim se sve češće susreću obrazovne vlasti u mnogim zemljama (Richardson i Watt, 2006). Stoga se posljednjih godina problem zapošljavanja i zadržavanja učitelja u sustavu obrazovanja prepoznaje kao jedno od ključnih pitanja obrazovne politike (Watt i Richardson, 2007). 


\section{Istraživanje}

\section{Cilj}

Cilj istraživanja bio je ispitati u kojem stupnju učitelji potiču kompetencije kod učenika te koliko su zadovoljni poslom i motivirani za rad. Također, cilj je bio ispitati i povezanost stupnja na kojem učitelji razredne nastave potiču kompetencije kod učenika te zadovoljstva poslom i motivacije učitelja za rad. Budući da se pretpostavilo kako će uzorak sudionika ovoga istraživanja biti heterogen s obzirom na broj godina radnog staža, cilj istraživanja bio je ispitati i povezanost godina radnog staža s prethodno navedenim varijablama.

\section{Sudionici}

Sudionici istraživanja bili su učitelji i učiteljice razredne nastave $(\mathrm{N}=341)$ osnovnih škola na području Slavonije i Baranje. 98,2\% $(\mathrm{N}=335)$ sudionika bilo je ženskog, a $1,8 \%(\mathrm{~N}=6)$ sudionika muškog spola. Sudionici su u prosjeku imali 14,6 godina staža ( $\mathrm{sd}=10,37) .29 \%$ sudionika imalo je od 0 do 5 godina radnog staža, 26\% sudionika od 6 do $15,38 \%$ sudionika imalo je 16 do 30 godina staža, dok je $7 \%$ sudionika imalo više od 30 godina radnog staža.

\section{Instrument}

U istraživanju je korišten Upitnik poticanja razvoja kompetencija učenika, učiteljskog zadovoljstva poslom i motivacije za rad (Borić i Borić, 2013) konstruiran za potrebe istraživanja (Prilog 1). Uz svaku česticu upitnika sudionik je trebao, na skali Likertovog tipa, zaokružiti jedan broj od 1 do $5(1=$ uopće se ne slažem, $2=$ donekle ne slažem, $3=$ niti se slažem, niti se ne slažem, 4= donekle se slažem, 5= u potpunosti se slažem).

Faktorskom analizom utvrđeno je kako se upitnik sastoji od dvije subskale; prva subskala sadržavala je 13, a druga 10 čestica. Rezultat za svaku subskalu oblikovao se kao zbroj čestica koje se odnose na tu subskalu. Rekodirane su vrijednosti čestica 5, 18 i 21. Minimalni mogući rezultat za prvu skalu iznosio je 13, a maksimalni 65. Minimalni mogući rezultat za drugu skalu iznosio je 10, a maksimalni 50. Veći 
rezultat na prvoj subskali označavao je veće poticanje razvoja kompetencija učenika, a veći rezultat na drugoj subskali veće zadovoljstvo poslom i višu motivaciju učitelja za rad.

\section{Postupak}

Upitnik poticanja razvoja kompetencija učenika, učiteljskog zadovoljstva poslom i motivacije za rad (Borić i Borić, 2013) podijeljen je učiteljicama i učiteljima razredne nastave na skupu stručnog usavršavanja održanom u Đakovu u kolovozu 2013. godine. Sudionicima je usmeno dana uputa za ispunjavanje upitnika, predstavljeni su im svrha i cilj istraživanja. Rečeno im je kako je sudjelovanje dobrovoljno i anonimno te kako će se podaci koristiti isključivo u svrhu znanstvenog istraživanja.

\section{Rezultati}

Prije početka statističke obrade podataka provjerena je distribucija rezultata dobivenih Upitnikom poticanja razvoja kompetencija učeni$k a$, učiteljskog zadovoljstva poslom i motivacije za rad (Borić i Borić, 2013) pomoću Kolmogorov-Smirnovljev testa normaliteta distribucije. Pokazalo se kako rezultati nisu raspoređeni po normalnoj distribuciji $\left(\mathrm{KS}_{(341)}=0,095 ; \mathrm{p}<0,01\right)$. Vizualnom inspekcijom histograma utvrđeno je kako je distribucija rezultata negativno asimetrična, tj. rezultati su pomaknuti prema višim vrijednostima.

Prije provođenja faktorske analize na podacima je izračunat Kaiser-Mayer-Olkinov test koji je ukazao na prikladnost podataka za provođenje faktorske analize. Bartlletov test pokazao se značajnim, što također ukazuje na prikladnost podataka za provođenje faktorske analize (Tablica 1).

Tablica 1. Kaiser-Meyer-Olkin i Bartlettov test

\begin{tabular}{|c|c|c|}
\hline \multicolumn{2}{|c|}{ Kaiser-Meyer-Olkin test prikladnosti uzorka } & 0,83 \\
\hline \multirow{3}{*}{ Bartlettov test sfericiteta } & aproksimacija hi kvadrata & 2317,25 \\
\cline { 2 - 3 } & stupnjevi slobode & 253 \\
\cline { 2 - 3 } & značajnost & 0,00 \\
\hline
\end{tabular}


Rezultati faktorske analize nakon primjene rotacije (principal components, direct oblimin) ukazali su kako se upitnik sastoji od dvije subskale: (1) subskale poticanja razvoja kompetencija kod učenika i (2) subskale zadovoljstva poslom i motivacije za rad učitelja (Tablica 2). Prva subskala sadržavala je 13, a druga 10 čestica. Rekodirane su čestice 5,18 i 21 . Utvrđeno je kako postoji niska korelacija između dvije subskale te iznosi $r=0,360, p<0,05$.

Tablica 2. Faktorska opterećenja 23 čestice upitnika za dva faktora

\begin{tabular}{|c|c|c|}
\hline Čestice & 1. faktor & 2. faktor \\
\hline 1. & 0,547 & \\
\hline 2. & 0,569 & \\
\hline 3. & 0,703 & \\
\hline 4. & 0,408 & \\
\hline 5. & 0,337 & \\
\hline 6. & 0,648 & \\
\hline 7. & 0,633 & \\
\hline 8. & 0,702 & \\
\hline 9. & 0,513 & \\
\hline 10. & 0,541 & \\
\hline 11. & 0,468 & \\
\hline 12. & 0,528 & \\
\hline 13. & 0,595 & \\
\hline 14. & & 0,864 \\
\hline 15. & & 0,819 \\
\hline 17. & & 0,643 \\
\hline 18. & & 0,488 \\
\hline 19. & & 0,373 \\
\hline 20. & & 0,719 \\
\hline 21. & & 0,595 \\
\hline 22. & & 0,451 \\
\hline 23. & & 0,447 \\
\hline
\end{tabular}

Cronbach alfa koeficijent unutarnje pouzdanosti pokazuje zadovoljavajuću unutarnju pouzdanost; za cijeli upitnik iznosi 0,829 , za subskalu poticanja razvoja kompetencija kod učenika iznosi 0,782 , dok za subskalu zadovoljstva poslom i motivacije za rad učitelja iznosi 0,776.

Iz rezultata je moguće uočiti kako su učitelji na subskalama Upitnika poticanja razvoja kompetencija učenika, učiteljskog zadovoljstva 
poslom i motivacije za rad postigli visoke prosječne rezultate (Tablica 3 i Tablica 4).

Tablica 3. Podaci deskriptivne statistike za: (1) subskalu poticanja razvoja kompetencija kod učenika i (2) subskalu zadovoljstva poslom i motivacije za $\operatorname{rad}(\mathrm{N}=341)$

\begin{tabular}{|c|c|c|c|c|c|c|}
\hline & $\begin{array}{c}\text { Teorijski } \\
\text { mogući } \\
\text { minimum }\end{array}$ & $\begin{array}{c}\text { Teorijski } \\
\text { mogući } \\
\text { maksimum }\end{array}$ & $\begin{array}{c}\text { Ostvareni } \\
\text { minimum }\end{array}$ & $\begin{array}{c}\text { Ostvareni } \\
\text { maksimum }\end{array}$ & M & SD \\
\hline $\begin{array}{c}\text { (1) Subskala poticanja } \\
\text { razvoja kompetencija } \\
\text { kod učenika }\end{array}$ & 13 & 65 & 24 & 65 & 58,94 & 4,58 \\
\hline $\begin{array}{c}\text { (2) Subskala } \\
\text { zadovoljstva poslom i } \\
\text { motivacije za rad }\end{array}$ & 10 & 50 & 13 & 50 & 43,26 & 4,98 \\
\hline
\end{tabular}

Tablica 4. Deskriptivni podaci za svaku česticu Upitnika poticanja razvoja kompetencija učenika, učiteljskog zadovoljstva poslom i motivacije za $\mathrm{rad}$

\begin{tabular}{|l|c|c|}
\hline & M & SD \\
\hline 1. Postavljam pitanja kojima potičem učenike na razmišljanje. & 4,73 & 0,559 \\
\hline $\begin{array}{l}\text { 2. Stalno ću tražiti bolje načine za poučavanje svakog nastavnog } \\
\text { predmeta. }\end{array}$ & 4,78 & 0,475 \\
\hline $\begin{array}{l}\text { 3. Kod učenika potičem razvijanje kompetencija, rješavanje } \\
\text { problema i razmišljanje o nastavnom sadržaju. }\end{array}$ & 4,63 & 0,582 \\
\hline 4. Kontinuirano i na razne načine pratim napredovanje učenika. & 4,58 & 0,662 \\
\hline 5. Isključivo pratim i ocjenjujem učenika pisanim ispitima znanja. & 2,21 & 1,222 \\
\hline $\begin{array}{l}\text { 6. Potičem učenike da istražuju i promatraju pojave i procese } \\
\text { i kada nisu u školi. }\end{array}$ & 4,52 & 0,620 \\
\hline 7. Povezujem sadržaje različitih nastavnih predmeta. & 4,68 & 0,539 \\
\hline 8. Potičem učenike na postavljanje pitanja. & 4,63 & 0,576 \\
\hline 9. Proširujem nastavne sadržaje ovisno o interesu i znatiželji učenika. & 4,40 & 0,690 \\
\hline 10. Nastojim učenike potaknuti da aktivno sudjeluju u nastavi. & 4,73 & 0,532 \\
\hline 11. Često postavljam pitanja učenicima. & 4,53 & 0,648 \\
\hline 12. Često uvodim nove nastavne metode i strategije. & 4,15 & 0,714 \\
\hline 13. Smatram da je razumijevanje nastavnih sadržaja jako važno. & 4,73 & 0,579 \\
\hline
\end{tabular}




\begin{tabular}{|l|c|c|}
\hline & M & SD \\
\hline 14. Jako sam zadovoljan/a izborom svog poziva. & 4,58 & 0,765 \\
\hline 15. Ponovno bih izabrao/la isti poziv. & 4,58 & 0,787 \\
\hline 16. Rado držim nastavu. & 4,72 & 0,647 \\
\hline 17. Ono što predajem zbilja mi je zanimljivo. & 4,25 & 0,866 \\
\hline 18. Nastavno gradivo koje predajem često mi je dosadno. & 2,13 & 1,168 \\
\hline 19. Osjećam se osposobljeno provesti tražene reforme u školstvu. & 3,83 & 0,951 \\
\hline 20. Studij sam upisao/la jer sam zaista želio/željela biti učiteljica. & 4,66 & 0,800 \\
\hline 21. Studij sam upisao/la jer ništa drugo nisam uspio/uspjela upisati. & 1,24 & 0,751 \\
\hline 22. Prisustvujem svim stručnim skupovima. & 4,06 & 0,944 \\
\hline 23. Za rad u nastavi pomažu mi stručni skupovi. & 3,91 & 0,868 \\
\hline
\end{tabular}

Budući da distribucija rezultata Upitnika poticanja razvoja kompetencija učenika, učiteljskog zadovoljstva poslom i motivacije za rad (Borić i Borić, 2013) značajno odstupa od normalne distribucije, kako bi se provjerilo postoji li statistički značajna povezanost između navedenih varijabli izračunat je Spearmanov koeficijent korelacije. Rezultati su pokazali kako između godina radnog staža te subskale učiteljskog zadovoljstva poslom i motivacije za rad postoji statistički značajna niska pozitivna korelacija $\mathrm{r}=0,176, \mathrm{p}<0,01$ (Tablica 5).

Tablica 5. Koeficijenti korelacije subskala Upitnika poticanja razvoja kompetencija učenika, učiteljskog zadovoljstva poslom i motivacije za rad $\mathrm{i}$ godina staža (Spearmanovi koeficijent korelacije)

\begin{tabular}{|c|c|c|c|c|}
\hline & & $\begin{array}{c}\text { Razvijanje } \\
\text { kompetencija } \\
\text { učenika }\end{array}$ & $\begin{array}{c}\text { Zadovoljstvo } \\
\text { poslom i motivacija } \\
\text { za rad }\end{array}$ & $\begin{array}{l}\text { Godine } \\
\text { staža }\end{array}$ \\
\hline \multirow{2}{*}{$\begin{array}{l}\text { Razvijanje } \\
\text { kompetencija učenika }\end{array}$} & $\mathrm{r}$ & & $0,360 * *$ & 0,073 \\
\hline & $\mathrm{p}$ & & 0,00 & 0,247 \\
\hline \multirow{2}{*}{$\begin{array}{l}\text { Zadovoljstvo poslom } \\
\text { i motivacija za rad }\end{array}$} & $\mathrm{r}$ & & & $0,176^{* *}$ \\
\hline & $\mathrm{p}$ & & & 0,005 \\
\hline
\end{tabular}

** značajno na razini rizika $\mathrm{p}<0,01$ 


\section{Rasprava}

Rezultati ovog istraživanja pokazali su kako su distribucije subskala Upitnika poticanja razvoja kompetencija učenika, učiteljskog zadovoljstva poslom i motivacije za rad negativno asimetrične, tj. rezultati su pomaknuti prema višim vrijednostima. Iz deskriptivnih rezultata može se zaključiti kako se učitelji kod učenika trude razviti kompetencije u visokom stupnju, kako su u prosjeku vrlo zadovoljni svojim poslom i visoko motivirani za rad. Ovo istraživanje u skladu je s rezultatima istraživanja Nikolić (2013) čiji su rezultati pokazali kako učitelji izjavljuju da se u velikoj mjeri rukovode ciljevima i ishodima nastavnoga predmeta, često povezuju nastavno gradivo sa svakodnevnim životom te njegov sadržaj sa sadržajima drugih predmeta, vrlo često koriste multimedijske sadržaje u nastavi, nastoje u velikoj mjeri potaknuti kreativnost kod učenika, prilagođavaju nastavno gradivo svakom učeniku, često prisustvuju stručnim usavršavanjima i vrlo su zadovoljni svojim radom u školi.

Rezultati ovog istraživanja pokazali su kako između stupnja u kojem učitelji potiču razvoj kompetencija kod učenika te zadovoljstva poslom i motiviranosti za rad učitelja postoji statistički značajna pozitivna korelacija $(r=0,360 ; p<0,01)$. Dakle, učitelji koji su zadovoljniji i motiviraniji svojim poslom u većoj se mjeri trude poticati razvoj kompetencija učenika. Ipak, utvrđena korelacija nije velika, što sugerira kako postoje i neki drugi faktori koji utječu na odnos između navedenih varijabli. Odnos navedenih varijabli potrebno je detaljnije ispitati u budućim istraživanjima: npr. ispitati povezanost stupnja u kojemu učitelji potiču razvoj kompetencija kod učenika, zadovoljstva poslom, različitih čimbenika intrinzične i ekstrinzične motivacije, razredne klime, resursa kojima škola raspolaže itd.

Neka istraživanja su pokazala da zadovoljstvo poslom raste s godinama staža i starosti (Bahtijarević Šiber, 1999): stariji i ljudi s većim radnim stažem imaju tendenciju biti više zadovoljni poslom, nego oni s manjim stažem na određenom poslu. To se događa zato što čovjek vremenom postaje sve bolji u svome poslu, daje veće rezultate pa je više i nagrađivan. Čak i oni koji nisu bili u početku zadovoljni svojim poslom, ako su na njemu ostali duže vrijeme, racionaliziraju svoju inertnost time što sebe uvjeravaju da su zadovoljni tim poslom. Ipak, neke prethodne analize trajanja radnog staža, zadovoljstva poslom i motivacije za rad pokazuju da su sudionici koji imaju najviše godina 
radnoga staža najmanje zadovoljni poslom i motivirani za rad, dok su sudionici s najmanje godina radnoga staža uglavnom djelomično motivirani i zadovoljni svojim poslom (Kanfer i Ackerman, 2004). Neka prethodna istraživanja utvrdila su kako nema razlike u zadovoljstvu poslom i motivaciji učitelja s obzirom na staž, npr. istraživanje Elezovića (2006) proučavalo je učitelje s manje i više godina staža te utvrdilo kako postoji velika podudarnost u određenim stavovima učitelja matematike usprkos činjenici da između prosječnih sudionika postoji razlika od gotovo 20 godina. Broj onih koji su zadovoljni pozivom bio je gotovo isti u obje skupine. Također, obje su skupine jednako ocijenile svoje zadovoljstvo vlastitim primanjima. Zbog navedenih nejednoznačnih rezultata prethodnih istraživanja, ovim se istraživanjem pokušala ispitati povezanost između godina radnog staža, zadovoljstva poslom i motivacije učitelja razredne nastave. Rezultati su pokazali kako između godina radnog staža te zadovoljstva poslom i motivacije za rad postoji vrlo niska statistički značajna pozitivna korelacija $(r=0,176, p<0,01)$, dok između radnog staža i stupnja u kojemu učitelji razvijaju kompetencije kod učenika ne postoji statistički značajna korelacija. Dakle, zadovoljstvo poslom i motivacija rastu s godinama staža iznimno malo, tj. u navedenim varijablama između sudionika različitih dobnih skupina postoji vrlo velika sličnost.

Osim sposobnosti, motivacija je jedan od najznačajnijih faktora uspjeha u učenju. Rezultati prijašnjih istraživanja pokazali su kako učenici kao razloge za demotiviranost najčešće navode monotonost gradiva, pristup učitelja učenicima, način na koji učitelj predaje i nedovoljnu motiviranost učitelja da prenesu gradivo učenicima. Učitelj je vrlo važan motivator u nastavi; ponašanje i stav učitelja utječe na motivaciju učenika (Andrilović, Čudina-Obradović, 1996). Učitelj tijekom poučavanja ima veliki utjecaj na motivaciju učenika stoga je važno da gradivo što zanimljivije prezentira te učenika na što aktivniji način uključi u proces učenja. Ako je učenicima način predavanja zanimljiv bit će ih lako motivirati na učenje - učiti će jer im je zanimljivo. Motivirani učitelji će na adekvatniji način prenijeti znanje na učenike, čime će oni lakše savladati gradivo te biti uspješniji u školi (Andrilović, ČudinaObradović, 1996). U skladu s navedenim, u budućim bi istraživanjima bilo korisno ispitati povezanost subskala Upitnika poticanja razvoja kompetencija učenika, učiteljskog zadovoljstva radom i motivacije za rad $i$ nekih mjera motivacije učenika. 


\section{Zaključak}

Rezultati istraživanja pokazali su kako se učitelji razredne nastave kod učenika trude razviti kompetencije u viskom stupnju te su u prosjeku visoko zadovoljni poslom i motivirani za rad. Utvrđeno je kako između zadovoljstva poslom i motiviranosti za rad učitelja te stupnja u kojemu učitelji potiču razvoj kompetencija kod učenika postoji statistički značajna niska pozitivna korelacija. Rezultati su pokazali kako između godina radnoga staža te zadovoljstva poslom i motivacije za rad učitelja također postoji statistički značajna niska pozitivna korelacija.

\section{Literatura}

Andrilović, Vlado i Čudina-Obradović, Mira (1996), Psihologija učenja i nastave, Zagreb: Školska knjiga.

Azevedo, Roger i Hadwin, Allyson Fiona (2005), »Introduction to special issue: Scaffolding self-regulated learning and metacognition: Implications for the design of computer-based scaffolds«, Instructional Science, 33, str. 367-379.

Bahtijarević Šiber, Fikreta (1999), Menadžment ljudskih potencijala, Zagreb: Golden Marketing.

Bognar, Ladislav i Matijević, Milan (2005), Didaktika, Zagreb: Školska knjiga.

Borić, Edita i Borić, Ivana (2013), »Motivacija studenata i utjecaj profesora na motivaciju studenata«, u: Czekus, Geza (ur.), Motivation - Attention - Discipli$n e$, Novi Sad: University of Novi Sad; Hungarian Language Teacher Training Faculty, str. 383-395.

Čorkalo Biruški, Dinka (2009), Primijenjena psihologija: pitanja i odgovori, Zagreb: Školska knjiga.

Dörnyei, Zoltán (2001), »New themes and approaches in second language motivation research«, Annual Review of Applied Linguistics, 21(3), str. 43-59.

Elezović, Neven (2006), »Motivacija nastavnika matematike - osvrt na anketu iz Rovinja«, Matematika i škola, 32(3), str. 57-63.

Jelavić, Filip (1998), Didaktika, Jastrebarsko: Naklada Slap.

Kanfer, Ruth i Ackerman, Phillip L. (2004), »Aging, adult development, and work motivation «, Academy of Management Review, 29(3), str. 440-458. doi: $10.2307 / 20159053$

Lončarić, Darko i Pejić Papak, P. (2009), »Profiliranje učiteljskih kompetencija«, Odgojne znanosti, 11(2), str. 479-497. 
Low, Guat Tin i Marican, Mukhthar (1993), »Selected factors and characteristics of staff motivation in Singapore primary school«, Educational Research $Q u$ arterly, 16(2), str. 11-17.

Marentič Požarnik, Barica (2000), Psihologija učenja in pouka, Ljubljana: DZS.

Marušić, Iris; Pavin Ivanec, Tea i Vizek Vidović, Vlasta (2010), »Neki prediktori motivacije za učenje u budućih učitelja i učiteljica«, Psihologijske teme, 19(1), str. 31-44.

Mihaliček, Sanja i Rijavec, Majda (2009), »Motivacija učitelja engleskog jezika za rad«, Napredak, 150(1), str. 39-53.

Nikolić, Marina (2013), Motivacija profesora i refleksija na motivaciju učenika, master rad, Beograd: Univerzitet Singidunum, Departman za poslediplomske studije.

Pelletier, Luc G.; Se'guin-Le'vesque, Chantal i Legault, Louise (2002), »Pressure from above and pressure from below as determinants of teachers' motivation and teaching behaviors «, Journal of Educational Psychology, 94(1), str. 186-196. doi: http://psycnet.apa.org/doi/10.1037/0022-0663.94.1.186

Reeve, Johnmarshall (2009), Razumijevanje motivacije i emocija, Jastrebarsko: Naklada Slap.

Reeve, Johnmarshall; Bolt, Elizabeth i Cai, Yi (1999), »Autonomy-supportive teachers: How they teach and motivate students«, Journal of Educational Psychology, 91(3), str. 537-548.

doi: http://psycnet.apa.org/doi/10.1037/0022-0663.91.3.537

Resman, Metod (2001), »Ravnatelj, vizija škole i motivacija učitelja za sudjelovanje«, u: Silov, M. (ur.), Suvremeno upravljanje i rukovođenje u školskom sustavu, Velika Gorica: Persona, str. 51-80.

Richardson, Paul W. i Watt, Helen M. G. (2006), »Who chooses teaching and why? Profiling characteristics and motivations across three Australian universities«, Asia-Pacific Journal of Teacher Education, 34(1), str. 27-56.

doi: https://doi.org/10.1080/13598660500480290

Sinclair, Catherine; Dowson, Martin i McInerney, Dennis Michael (2006), »Motivations to teach: Psychometric perspectives across the first semester of teacher education«, Teachers College Record, 108(6), str. 1132-1154. doi: https://doi.org/10.1111/j.1467-9620.2006.00688.x

Thody, Angela (1992), Moving to Management (School Governors in 1990s), London: David Fulton Publishers.

Tot, Daria (2010), »Učeničke kompetencije i suvremena nastava«, Odgojne znanosti, 12(1), str. 65-78.

Vizek Vidović, Vlasta; Rijavec, Majda; Vlahović-Štetić, Vesna i Miljković, Dubravka (2003), Psihologija obrazovanja, Zagreb: IEP. 
Watt, Helen M. G. i Richardson, Paul W. (2008), »Motivations, perceptions, and aspirations concerning teaching as a career for different types of beginning teachers «, Learning and Instruction, 18, str. 408-428.

doi: https://doi.org/10.1016/j.learninstruc.2008.06.002

Watt, Helen M. G. i Richardson, Paul W. (2007), »Motivational factors influencing teaching as a career choice: Development and validation of the FIT-Choice Scale«, Journal of Experimental Education, 75(3), str. 167-202.

doi: https://doi.org/10.3200/JEXE.75.3.167-202

Watt, Helen M. G.; Richardson, Paul W. i Tysvaer, Nicole M. (2007), »What motivates people to change out of business-related careers into teaching?«, u: Ozbilgin, Mustafa F. i Malach-Pines, Ayala (ur.), Career Choice in Management and Entrepreneurship - A Research Companion, Edward Elgar Publishing, str. 219-239.

Woolfolk, Anita (2008), Educational Psychology. Active Learning Edition, 2. izdanje, Boston, MA: Allyn i Bacon.

\section{TEACHERS' JOB SATISFACTION, WORK MOTIVATION, AND ENCOURAGEMENT OF COMPETENCES AMONG PUPILS}

\section{Edita Borić}

The aim of this study was to examine the degree in which teachers encourage competences in pupils, how much are they satisfied with their job and motivated for work. The aim was to examine the connection between the degree in which teachers encourage competence in pupils, job satisfaction, motivation for work and years of experience. Participants were school teachers $(N=341)$. The study used Questionnaire of teachers' encouragement of competences among pupils, job satisfaction and motivation for work (Borić and Borić, 2013) designed for research purposes. Factor analysis indicated that the questionnaire consists of: (1) subscale of development of competencies among pupils and (2) subscale of teachers'job satisfaction and motivation. Results suggested that there is a correlation between the subscales $(r=0,360, p<0,05)$, that teachers are highly satisfied with their job, motivated for work and strive to develop pupils' competence in high degree. The results showed that there is statistically significant low positive correlation between the years of service and subscale of job satisfaction and work motivation $(r=0,176, p<0,01)$.

Key words: teachers' quality, work experience, classroom teaching 


\section{Prilog 1. Upitnik poticanja razvoja kompetencija učenika, učiteljskog zadovoljstva poslom i motivacije za rad}

Spol

\section{Godine radnog staža}

Molimo Vas da za svaku od navedenih tvrdnji zaokružite jedan od ponuđenih brojeva ( $1=$ uopće se ne slažem, $2=$ donekle ne slažem, $3=$ niti se slažem, niti se ne slažem, $4=$ donekle se slažem, $5=$ u potpunosti se slažem).

\begin{tabular}{|c|c|c|c|c|c|}
\hline 1. Postavljam pitanja kojima potičem učenike na razmišljanje. & 1 & 2 & 3 & 4 & 5 \\
\hline 2. Stalno ću tražiti bolje načine za poučavanje svakog nastavnog predmeta. & 1 & 2 & 3 & 4 & 5 \\
\hline $\begin{array}{l}\text { 3. Kod učenika potičem razvijanje kompetencija, rješavanje problema i } \\
\text { razmišljanje o nastavnom sadržaju. }\end{array}$ & 1 & 2 & 3 & 4 & 5 \\
\hline 4. Kontinuirano i na razne načine pratim napredovanje učenika. & 1 & 2 & 3 & 4 & 5 \\
\hline 5. Isključivo pratim i ocjenjujem učenika pisanim ispitima znanja. * & 1 & 2 & 3 & 4 & 5 \\
\hline $\begin{array}{l}\text { 6. Potičem učenike da istražuju i promatraju pojave i procese } \\
\text { i kada nisu u školi. }\end{array}$ & 1 & 2 & 3 & 4 & 5 \\
\hline 7. Povezujem sadržaje različitih nastavnih predmeta. & 1 & 2 & 3 & 4 & 5 \\
\hline 8. Potičem učenike na postavljanje pitanja. & 1 & 2 & 3 & 4 & 5 \\
\hline 9. Proširujem nastavne sadržaje ovisno o interesu i znatiželji učenika. & 1 & 2 & 3 & 4 & 5 \\
\hline 10. Nastojim učenike potaknuti da aktivno sudjeluju u nastavi. & 1 & 2 & 3 & 4 & 5 \\
\hline 11. Često postavljam pitanja učenicima. & 1 & 2 & 3 & 4 & 5 \\
\hline 12. Često uvodim nove nastavne metode i strategije. & 1 & 2 & 3 & 4 & 5 \\
\hline 13. Smatram da je razumijevanje nastavnih sadržaja jako važno. & 1 & 2 & 3 & 4 & 5 \\
\hline 14. Jako sam zadovoljan/a izborom svog poziva. & 1 & 2 & 3 & 4 & 5 \\
\hline 15. Ponovno bih izabrao/la isti poziv. & 1 & 2 & 3 & 4 & 5 \\
\hline 16. Rado držim nastavu. & 1 & 2 & 3 & 4 & 5 \\
\hline 17. Ono što predajem zbilja mi je zanimljivo. & 1 & 2 & 3 & 4 & 5 \\
\hline 18. Nastavno gradivo koje predajem često mi je dosadno. ${ }^{*}$ & 1 & 2 & 3 & 4 & 5 \\
\hline 19. Osjećam se osposobljeno provesti tražene reforme u školstvu. & 1 & 2 & 3 & 4 & 5 \\
\hline 20. Studij sam upisao/la jer sam zaista želio/željela biti učiteljica. & 1 & 2 & 3 & 4 & 5 \\
\hline 21. Studij sam upisao/la jer ništa drugo nisam uspio/uspjela upisati. * & 1 & 2 & 3 & 4 & 5 \\
\hline 22. Prisustvujem svim stručnim skupovima. & 1 & 2 & 3 & 4 & 5 \\
\hline 23. Za rad u nastavi pomažu mi stručni skupovi. & 1 & 2 & 3 & 4 & 5 \\
\hline
\end{tabular}

* rekodirane čestice 